\title{
Inhibition of melanin production by anthracenone dimer glycosides isolated from Cassia auriculata seeds
}

\author{
Weicheng Wang ${ }^{1} \cdot$ Yi Zhang $^{1,2} \cdot$ Souichi Nakashima ${ }^{1,3} \cdot$ Seikou Nakamura ${ }^{1} \cdot$ Tao Wang $^{1,2} \cdot$ Masayuki Yoshikawa ${ }^{1}$. \\ Hisashi Matsuda ${ }^{1}[$
}

Received: 23 October 2018 / Accepted: 28 December 2018 / Published online: 7 March 2019

(c) The Author(s) 2019, corrected publication 2020

\begin{abstract}
The methanol extract of Cassia auriculata seeds was found to inhibit melanogenesis in B16 melanoma 4A5 cells under conditions of theophylline stimulation. Two new phlegmacin-type anthracenone dimer glycosides, auriculataosides A and $\mathrm{B}$, were isolated from the active methanol fraction, and their inhibitory effects were observed in the concentration range of 0.03 to $0.3 \mu \mathrm{M}$. Inhibition of microphthalmia-associated transcription factor, tyrosinase, tyrosinase-related protein (TRP)-1, and TRP-2 protein expression was observed, suggesting that the inhibition of these factors is part of the mechanism of action underlying melanogenesis inhibition.
\end{abstract}

Keywords Cassia auriculate $\cdot$ Anthracenone dimer glycoside $\cdot$ Melanogenesis inhibitor $\cdot$ Mechanism of action

\section{Introduction}

Melanocytes originate from the ganglion in the embryonic phase and are distributed in the epidermal basal layer, hair follicles, uvea of the eye, soft brain membrane, oral mucosa, inner ear, peritoneal membrane, and eye socket. The formation of cutaneous melanin is a normal physiological phenomenon that plays an important role in protecting skin from UV injury $[1,2]$. However, melanin production can be promoted-for example, by lifestyle choices, long-term use of the psychotic drug chlorpromazine and the anti-epileptic drug phenytoin sodium, among others [3]. Excessive melanin deposition causes such pigmentary disorders such as melasma, spots, and senile pigment spots [4]. In addition,

Electronic supplementary material The online version of this article (https://doi.org/10.1007/s11418-018-01276-2) contains supplementary material, which is available to authorized users.

Hisashi Matsuda

matsuda@mb.kyoto-phu.ac.jp

1 Kyoto Pharmaceutical University, Misasagi, Yamashina-ku, Kyoto 607-8412, Japan

2 Tianjin State Key Laboratory of Modern Chinese Medicine, Tianjin University of Traditional Chinese Medicine, 312 Anshanxi Road, Nankai District, Tianjin 300193, China

3 N.T.H Co., Ltd., 4F Sky-ebisu Bldg, 1-8-11 Ebisu, Shibuya-ku, Tokyo 150-0013, Japan drugs such as chlorpromazine, streptomycin, chloroquine, and phenothiazine tend to electrostatically bind to melanin easily and accumulate in the body, possibly causing side effects [5-7]. Inhibitors of melanin production are available, but those currently in use do not provide optimum protection because they induce side effects such as allergies and damage the stratum corneum, etc. Clearly, a melanin production inhibitor that has stronger effects and fewer side effects is desired. Our group has been searching for melanogenesis inhibitors in theophylline-stimulated B16 melanoma 4A5 cells treated with natural medicines and have reported various melanin production inhibitors, such as diarylheptanoids; flavonoids; triterpene saponins; benzylisoquinoline, carbazole, and pyrrolidinoindoline alkaloids; and lignan dicarboxylates [8-20].

The leguminous plant Cassia auriculata is a perennial evergreen shrub that is native to India, Sri Lanka, and other parts of Asia. The flower, leaves, stem, root, and unripe fruit of this shrub have been used for the treatment of diabetes, conjunctivitis, and skin diseases in Ayurveda, Indian traditional medicine. We have reported the isolation of various active compounds, including benzocoumarins, flavones, flavonols, and a flavanol dimer, with hepatoprotective effects in vitro from the leaves of $C$. auriculate [21]. However, little research has been done on the seed components of this plant and their biological activities [22]. 
In the study reported here we found that the methanol $(\mathrm{MeOH})$ extract of $C$. auriculata seeds inhibited melanogenesis. We used bioassay-guided isolation techniques and further isolated two new anthracenone dimer glycosides, auriculataosides A (1) and B (2), as the active compounds. The isolation and chemical elucidation of $\mathbf{1}$ and $\mathbf{2}$ as well as their modes of action are also discussed herein.

\section{Results and discussion}

\section{Extraction and isolation of glycosides 1-4 from the seeds of $C$. auriculata}

Seeds of C. auriculata (3929 g) were extracted with $\mathrm{MeOH}$ three times under reflux to yield a $\mathrm{MeOH}$ extract $(430.6 \mathrm{~g}$, yield: $10.96 \%$ ). To defat the $\mathrm{MeOH}$ extract, part (399.0 g) of the extract was suspended in $\mathrm{H}_{2} \mathrm{O}$ and extracted with $n$-hexane to give an $n$-hexane-soluble fraction ( $46.4 \mathrm{~g}, 1.27 \%$ ) and a $\mathrm{H}_{2} \mathrm{O}$-soluble fraction $(352.6 \mathrm{~g}, 9.63 \%)$. Part of the $\mathrm{H}_{2} \mathrm{O}$-soluble fraction ( $322.7 \mathrm{~g}$ ) was subjected to Diaion HP-20 column chromatography and eluted sequentially, first with $\mathrm{H}_{2} \mathrm{O}$ and then with $\mathrm{MeOH}$, to obtain the $\mathrm{MeOH}$-eluted fraction $(63.2 \mathrm{~g}, 1.89 \%)$ and $\mathrm{H}_{2} \mathrm{O}$-eluted fraction $(259.5 \mathrm{~g}$, 7.41\%). The $\mathrm{MeOH}$-eluted fraction was repeatedly separated and purified using normal silica gel $\left(\mathrm{CHCl}_{3}-\mathrm{MeOH}\right)$ and reversed-phase (ODS) $\left(\mathrm{MeOH}-\mathrm{H}_{2} \mathrm{O}\right)$ column chromatography and HPLC (YMC-Pack ODS-5-A, $250 \times 20 \mathrm{~mm}$ i.d., $\mathrm{MeOH}-\mathrm{H}_{2} \mathrm{O}$ or $\mathrm{CH}_{3} \mathrm{CN}-\mathrm{H}_{2} \mathrm{O}$ ). These efforts yielded two new anthracenone dimer glycosides named auriculataosides A (1, 0.011\%) and B (2, 0.0084\%) and known anthraquinone glycosides rumejaposides $\mathrm{E}(\mathbf{3}, 0.00038 \%)$ and $\mathrm{F}(\mathbf{4}$, $0.00026 \%$ ) [23] (Fig. 1).

\section{Structures of auriculataosides A (1) and B (2)}

Auriculataosides A (1) and B (2) were obtained as red powder with negative optical rotation $\left(\mathbf{1}:[\alpha]_{D}^{24}-129.5^{\circ} ; \mathbf{2}:[\alpha]_{\mathrm{D}}^{22}\right.$ $-41.3^{\circ}$ in 1,4-dioxane). FAB-MS measurement revealed a pseudo molecular ion peak at $\mathrm{m} / z 755(\mathrm{M}+\mathrm{Na})^{+}$, respectively, and the molecular formula of both compounds was determined as $\mathrm{C}_{38} \mathrm{H}_{36} \mathrm{O}_{15}$ by high-resolution FAB-MS measurement. Their IR absorption spectra showed absorptions (1 and 2: 3450,1655 , and $1070 \mathrm{~cm}^{-1}$ ) ascribable to hydroxy, carbonyl, and ether functions, respectively. The ${ }^{1} \mathrm{H}-\mathrm{NMR}$ (DMSO- $d_{6}$ ) and the ${ }^{13} \mathrm{C}$-NMR spectra of $\mathbf{1}$ and $\mathbf{2}$ (Table 1), the signals of which were assigned based on the results of various NMR experiments, showed resonances assignable to two methyls [1: $\delta 1.15,2.24$ (3H each, both s, $\mathrm{CH}_{3}-3^{\prime}, 3$ ); 2: $\delta 1.18,2.24$ (3H each, both s, $\left.\mathrm{CH}_{3}-3^{\prime}, 3\right)$ ], two methylenes [1: $\delta 2.61\left(2 \mathrm{H}, \mathrm{br} \mathrm{s}, \mathrm{H}_{2}-4^{\prime}\right), 2.74,2.88(1 \mathrm{H}$ each, both d, $\left.J=16.8 \mathrm{~Hz}, \mathrm{H}_{2}-2^{\prime}\right) ; 2: \delta 2.57,2.75$ (1H each, both d, $\left.J=16.2 \mathrm{~Hz}, \mathrm{H}_{2}-4^{\prime}\right), 2.72,2.90$ (1H each, both $\mathrm{d}, J=16.8 \mathrm{~Hz}$,

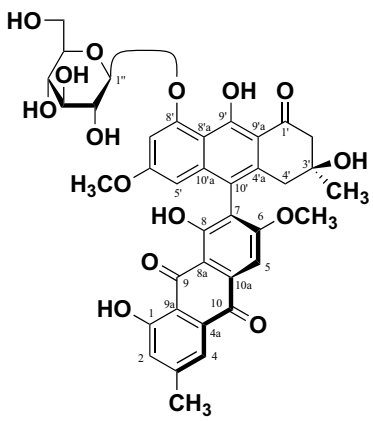

auriculataoside A (1)

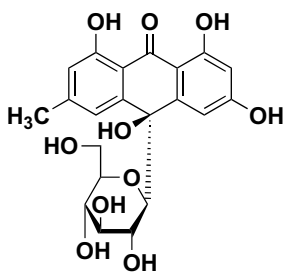

rumeojaposide E (3)

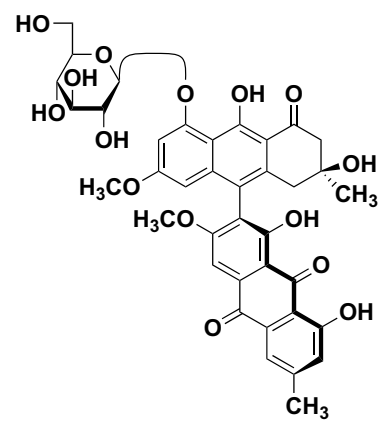

auriculataoside B (2)

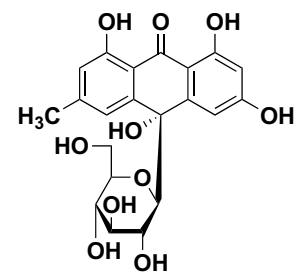

rumejaposide $\mathrm{F}$ (4)
Fig. 1 Chemical structures of anthracenone glycosides 1-4

$\left.\mathrm{H}_{2} 2^{\prime}\right)$ ], two methoxy groups [1: $\delta 3.65,3.89$ (3H each, both $\mathrm{s}, \mathrm{OCH}_{3}-6^{\prime}, 6$ ); 2: $\delta 3.66,3.85$ (3H each, both s, $\mathrm{OCH}_{3}-6^{\prime}$, 6)], five aromatic protons [1: $\delta 6.20,6.88(1 \mathrm{H}$ each, both d, $\left.J=2.1 \mathrm{~Hz}, \mathrm{H}-5^{\prime}, 7^{\prime}\right), 7.22,7.59$ (1H each, both br s, H-2, 4), $7.55(1 \mathrm{H}, \mathrm{s}, \mathrm{H}-5) ; 2: \delta 6.20,6.89(1 \mathrm{H}$ each, br s, H-5', 7 ') $7.18,7.53(1 \mathrm{H}$ each, both br s, H-2, 4), $7.52(1 \mathrm{H}, \mathrm{s}$, H-5)], and a $\beta$-D-glucopyranosyl moiety $[1: \delta 5.04(1 \mathrm{H}, \mathrm{d}, J$ $\left.\left.=7.7 \mathrm{~Hz}, \mathrm{H}-1^{\prime \prime}\right) ; 2: \delta 5.02\left(1 \mathrm{H}, \mathrm{d}, J=7.7 \mathrm{~Hz}, \mathrm{H}-1^{\prime \prime}\right)\right]$.

The COSY-Double Quantum Filter and HMBC experiments revealed both $\mathbf{1}$ and $\mathbf{2}$ to be anthracenone derivatives with a glucopyranosyl moiety at position 8 . Acid hydrolysis of 1 and 2 with $1.0 \mathrm{M} \mathrm{HCl}$ yielded D-glucose, which was identified by HPLC equipped with an optical rotation detector. In the HMBC experiments, ${ }^{1} \mathrm{H}_{-}{ }^{13} \mathrm{C}$ long-range correlations were observed between the following proton-carbon pairs (H-4 and C-10; $\mathrm{H}-5$ and C-6, 8a, 10; $\mathrm{H}-2^{\prime}$ and C-1', $9^{\prime} \mathrm{a}, \mathrm{CH}_{3}-3 ; \mathrm{H}-4^{\prime}$ and $\mathrm{C}-10^{\prime}, \mathrm{CH}_{3}-3^{\prime} ; \mathrm{H}-5^{\prime}$ and C-6', 7', 10'; $\mathrm{H}-7^{\prime}$ and $\mathrm{C}^{-5} 5^{\prime}, 8^{\prime}, 8^{\prime} \mathrm{a} ; \mathrm{H}-1^{\prime \prime}$ and $\mathrm{C}-8^{\prime} ; \mathrm{CH}_{3}-3$ and $\mathrm{C}-2,3$, 4; $\mathrm{CH}_{3}-3^{\prime}$ and $\mathrm{C}^{-2} 2^{\prime}, 3^{\prime}, 4^{\prime}$; $\mathrm{OH}-1$ and $\mathrm{C}-1,2,9 \mathrm{a} ; \mathrm{OH}-8$ and $\mathrm{C}-7,8,8 \mathrm{a} ; \mathrm{OH}-3^{\prime}$ and $\mathrm{C}^{-} 3^{\prime}, 4^{\prime}, \mathrm{CH}_{3}-3^{\prime}$; $\mathrm{OH}-9^{\prime}$ and $\mathrm{C}-8^{\prime} \mathrm{a}, 9^{\prime}$, $9^{\prime}$ a; $\mathrm{OCH}_{3}-6$ and $\mathrm{C}-6$; $\mathrm{OCH}_{3}-6^{\prime}$ and C-6') (Fig. 2). NOESY experiments on $\mathbf{1}$ and $\mathbf{2}$ showed correlations between the following proton-proton pairs (H-1" and $\mathrm{H}^{-} 7^{\prime} ; \mathrm{CH}_{3}-3$ and $\mathrm{H}-2$, 4; $\mathrm{OCH}_{3}-6$ and $\mathrm{H}-4^{\prime}, 5,5^{\prime}$; $\mathrm{OCH}_{3}-6^{\prime}$ and $\mathrm{H}-5^{\prime}, 7^{\prime}$ ) (Fig. 2). These results showed that $\mathbf{1}$ and $\mathbf{2}$ are phlegmacin-type anthracenone dimers in which C-7 is connected to C-10' and that both $\mathbf{1}$ and $\mathbf{2}$ are mutually atropisomers, as shown.

The absolute configurations of the asymmetric axes in $\mathbf{1}$ and $\mathbf{2}$ were determined by comparing their CD spectra 
Table $1{ }^{13} \mathrm{C}$-NMR

spectroscopic data for anthracenone dimer glycosides auriculataosides A (1) and B (2) in DMSO- $d_{6}$

\begin{tabular}{llllrrlrr}
\hline Position & $\mathbf{1}$ & $\mathbf{2}$ & Position & \multicolumn{1}{c}{$\mathbf{1}$} & \multicolumn{1}{c}{$\mathbf{2}$} & Position & $\mathbf{1}$ & $\mathbf{2}$ \\
\hline 1 & 161.4 & 161.4 & $1^{\prime}$ & 204.1 & 204.2 & $1^{\prime \prime}$ & 101.6 & 101.8 \\
2 & 124.2 & 124.2 & $2^{\prime}$ & 51.6 & 51.4 & $2^{\prime \prime}$ & 73.4 & 73.4 \\
3 & 148.6 & 148.6 & $3^{\prime}$ & 68.8 & 68.8 & $3^{\prime \prime}$ & 76.4 & 76.4 \\
4 & 120.6 & 120.6 & $4^{\prime}$ & 41.2 & 41.0 & $4^{\prime \prime}$ & 69.8 & 69.8 \\
$4 \mathrm{a}$ & 132.8 & 132.6 & $4^{\prime} \mathrm{a}$ & 136.6 & 136.7 & $5^{\prime \prime}$ & 77.3 & 77.3 \\
5 & 103.2 & 103.3 & $5^{\prime}$ & 99.6 & 99.4 & $6^{\prime \prime}$ & 60.8 & 60.8 \\
6 & 163.8 & 163.8 & $6^{\prime}$ & 161.4 & 161.4 & $\mathrm{CH}_{3}-3$ & 21.5 & 21.5 \\
7 & 120.1 & 120.1 & $7^{\prime}$ & 100.7 & 100.8 & $\mathrm{CH}_{3}-3^{\prime}$ & 28.2 & 28.5 \\
8 & 161.1 & 161.2 & $8^{\prime}$ & 159.2 & 159.3 & $\mathrm{OCH}_{3}-6$ & 56.8 & 56.5 \\
$8 \mathrm{a}$ & 110.7 & 110.7 & $8^{\prime} \mathrm{a}$ & 109.6 & 109.6 & $\mathrm{OCH}_{3}-6^{\prime}$ & 55.1 & 55.1 \\
9 & 190.5 & 190.5 & $9^{\prime}$ & 164.7 & 164.6 & & & \\
$9 \mathrm{a}$ & 113.4 & 113.4 & $9^{\prime} \mathrm{a}$ & 109.4 & 109.4 & & & \\
10 & 181.3 & 181.2 & $10^{\prime}$ & 117.1 & 117.1 & & & \\
$10 \mathrm{a}$ & 134.6 & 134.5 & $10^{\prime} \mathrm{a}$ & 139.4 & 139.4 & & & \\
\hline
\end{tabular}

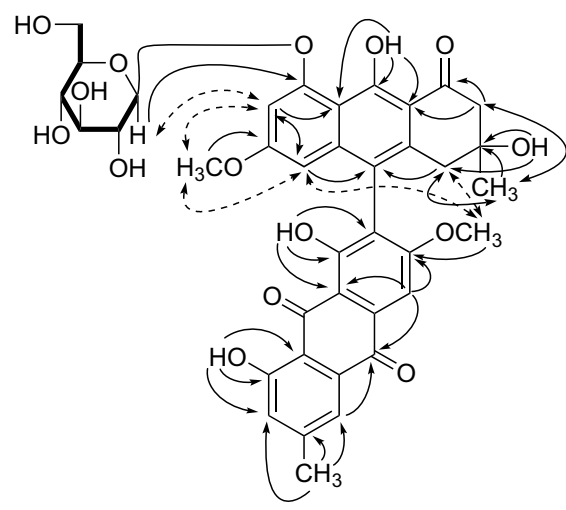

auriculataosides A (1) and B (2)

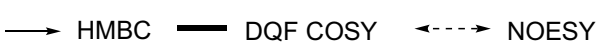

Fig. 2 Important two dimensional-NMR correlations of auriculataosides A (1) and B (2). DQF Double Quantum Filter

with those of known anthracenone dimers. Elsworth et al. reported that phlegmacin-type anthracenone dimer $\left(3^{\prime} S, P\right)$ anhydrophlegmacin-9,10-quinone 8'-O-methyl ether [S1; see Electronic Supplementary Material (ESM) Fig. S1] having the $S$ configuration at the $7-10^{\prime}$ stereostructure exhibited a positive Cotton effect $(\Delta \varepsilon+22.6)$ at $267 \mathrm{~nm}$ and a negative Cotton effect $(\Delta \varepsilon-34.4)$ at $283 \mathrm{~nm}$ [24]. The Cotton effects of $\mathbf{S 1}$ centered around $275 \mathrm{~nm}$ is in agreement with the anticlockwise twist between the napthalenoid and anthraquinone rings. By subsequent application of the Prelog-Helmchen rules [25], these authors determined the axial configurations of S1 [24]. As shown in ESM Fig. S2, 2 showed the very similar CD spectrum of a positive Cotton effect $(\Delta \varepsilon+28.3)$ at $270 \mathrm{~nm}$ and a negative Cotton effect $(\Delta \varepsilon-27.9)$ at $288 \mathrm{~nm}$; its absolute configuration was determined to be $S$. To the contrary, as $\mathbf{1}$ showed the opposite axial configuration to 2 based on a negative Cotton effect $(\Delta \varepsilon-38.0)$ at $270 \mathrm{~nm}$ and a positive Cotton effect $(\Delta \varepsilon+25.5)$ at $284 \mathrm{~nm}$, its absolute configuration was determined to be $R$ at the $7-10^{\prime}$ stereostructure.

With regard to the stereostructure at the 3'-position, Elsworth et al. also summarized that the comparison of the chemical shift and coupling constants of $4^{\prime}-\mathrm{H}_{\mathrm{ax}}$ and $4^{\prime}-\mathrm{H}_{\mathrm{eq}}$ with the corresponding data for other phlegmacins revealed an empirical relationship between the difference $(\Delta \delta)$ in the chemical shift of these methylene protons and the relative configuration between the C- $3^{\prime}$ stereostructure and biaryl axis [24]. Thus, when the C-3' hydroxy group is on the same side of the $\mathrm{C}-10^{\prime}$-anthracenone (anthraquinone) ring ('syn'), chemical shift differences $(\Delta \delta)$ between the 4 ' $-\mathrm{H}_{\mathrm{ax}}$ and $4^{\prime}-\mathrm{H}_{\mathrm{eq}}$ trend to be large $(\Delta \delta=0.15-0.25)$. However, when the $\mathrm{C}-3$ ' hydroxy group and the $\mathrm{C}-10^{\prime}$-anthracenone (anthraquinone) ring are on apposite sides of the molecules ('anti'), $\Delta \delta$ are often much smaller ( $\Delta \delta \leq 0.08 \mathrm{ppm})$. In ${ }^{1} \mathrm{H}$ NMR spectra, the $\Delta \delta$ between $4^{\prime}-\mathrm{H}_{\mathrm{ax}}$ and $4^{\prime}-\mathrm{H}_{\mathrm{eq}}$ of $\mathbf{1}$ were the same value $(0 \mathrm{ppm})$, and those of 2 were $0.18 \mathrm{ppm}$, suggesting that the configurations at the 3'-position of $\mathbf{1}$ and $\mathbf{2}$ were $S$. Thus, the chemical structures of auriculataosides A (1) and B (2) were determined as shown.

Known compounds $\mathbf{3}$ and $\mathbf{4}$ were identified by comparison of their physical data $\left([\alpha]_{\mathrm{D}},{ }^{1} \mathrm{H}-\right.$ and ${ }^{13} \mathrm{C}-\mathrm{NMR}$, and MS spectra) with reported values [23].

\section{Effects on melanogenesis in B16 melanoma 4A5 cells}

Melanocytes are stimulated by many effectors, including UV radiation and $\alpha$-melanocyte-stimulating hormone ( $\alpha$-MSH) $[26,27]$. It is generally accepted that the cAMP pathway plays a key role in the regulation of melanogenesis and that cAMP is involved in $\alpha-\mathrm{MSH}$-stimulated signal transduction 
$[28,29]$. B16 melanoma cells have often been used in experiments of melanogenesis stimulated by $\alpha$-MSH or phosphodiesterase inhibitors. Here, we used phosphodiesterase inhibitor theophylline to stimulate B16 melanoma 4A5 cells.

As shown in Table 2, the $\mathrm{MeOH}$ extract and the $\mathrm{MeOH}-$ eluted fraction exhibited significant inhibition on melanogenesis in the concentration range of $1-100 \mu \mathrm{g} / \mathrm{mL}$, and the $\mathrm{MeOH}$-eluted fraction exhibited cytotoxicity at $100 \mu \mathrm{g} / \mathrm{mL}$. As the $\mathrm{MeOH}$-eluted fraction exhibited inhibitory effects on melanogenesis in these cells, the effects of 1-4, which are components of the $\mathrm{MeOH}$-eluted fraction, on melanogenesis were examined. Compounds $\mathbf{1}$ and $\mathbf{2}$ showed significantly stronger melanogenesis inhibitory effects $(45.1 \%$ and $36.5 \%$ inhibition, respectively, at $0.3 \mu \mathrm{M}$ ) than the reference compound $\beta$-arbutin (32.1\% inhibition at $100 \mu \mathrm{M})$ (Table 3$)$, and both compounds showed cytotoxicity at $1 \mu \mathrm{M}$ (Table 3 ). Compounds 3 and $\mathbf{4}$ showed weaker melanogenesis inhibitory effects and lower cytotoxicity than did compounds $\mathbf{1}$ and $\mathbf{2}$; however, $\mathbf{1}$ and $\mathbf{2}$ did not show cytotoxicity toward human dermal fibroblasts (HDF) at 0.01-1 $\mu \mathrm{M}$ (Table 4), suggesting that they selectively inhibited the proliferation of melanoma cells.

\section{Effects of anthracenone glycosides 1-4 on tyrosinase}

In human and mouse, melanin is produced from tyrosine as the starting material by the oxidation and polymerization of dopachrome produced by such enzymes as tyrosinase and tyrosinase-related protein (TRP)-1, and TRP-2. Therefore, to investigate the mechanism of action underlying melanogenesis inhibition, we examined the inhibition of tyrosinase, the main melanin synthetase, using mushroom- or melanoma-derived tyrosinase. Kojic acid and $\beta$-arbutin [8, 9] were used as reference compounds.

Mushroom-derived tyrosinase has been conventionally used for the development of tyrosinase inhibitors [8, 9]. In order to investigate the mechanism of action underlying melanogenesis inhibition, we examined the inhibitory effects of anthracenone glycosides 1-4 on mushroom-derived tyrosinase in the concentration range of 0.01 to $100 \mu \mathrm{M}$. No significant inhibitory effect was found for auriculataosides A (1) and B (2) even at the high concentration of $100 \mu \mathrm{M}$ (Table 5).

On the other hand, it has been reported that there is a considerable difference in the inhibitory effects of inhibitors on mushroom-derived tyrosinase and melanoma-derived tyrosinase [30-33]. Therefore, the inhibitory effect of the isolated anthracenone glycosides and reference compounds on melanoma-derived crude tyrosinase was investigated in the concentration range of 0.01 to $1 \mu \mathrm{M}$, which is the effective concentration range for melanogenesis. Kojic acid, a reference compound, exhibited a significant inhibitory effect on mushroom-derived tyrosinase but not on melanoma-derived tyrosinase. Compounds 1-4 did not inhibit the melanomaderived tyrosinase at $1 \mu \mathrm{M}$ (Table 6). These findings suggest that tyrosinase inhibition is not the main mechanism underlying melanin inhibition.

\section{Effects of anthracenone glycosides 1-4 on autoxidation}

In melanogenesis, dopachrome is synthesized from tyrosine through L-DOPA (L-3,4-dihydroxyphenylalanine) and dopaquinone by the action of an enzyme, such as tyrosinase. Produced dopachrome is automatically oxidized and polymerized into melanin [34]. Therefore, to investigate the mechanism of action underlying melanogenesis inhibition by

Table 2 Inhibitory effects of $\mathrm{MeOH}$ extract and its fractions from the seeds of $C$. auriculata at different concentrations on melanogenesis and cell viability in B16 melanoma 4A5 cells

\begin{tabular}{|c|c|c|c|c|c|c|c|}
\hline \multirow[t]{2}{*}{ Sample } & \multicolumn{6}{|c|}{ Inhibition (\%) } & \multirow{2}{*}{$\mathrm{IC}_{50}(\mu \mathrm{g} / \mathrm{mL})$} \\
\hline & $0 \mu \mathrm{g} / \mathrm{mL}$ & $1 \mu \mathrm{g} / \mathrm{mL}$ & $3 \mu \mathrm{g} / \mathrm{mL}$ & $10 \mu \mathrm{g} / \mathrm{mL}$ & $30 \mu \mathrm{g} / \mathrm{mL}$ & $100 \mu \mathrm{g} / \mathrm{mL}$ & \\
\hline $\mathrm{MeOH}$ extract & $0.0 \pm 1.3$ & $29.2 \pm 2.9^{* *}$ & $28.7 \pm 2.6^{* *}$ & $32.0 \pm 1.7 * *$ & $35.1 \pm 2.7 * *$ & $36.1 \pm 3.7 * *$ & - \\
\hline $\mathrm{MeOH}$-eluted fraction & $0.0 \pm 2.7$ & $-2.0 \pm 3.6$ & $7.2 \pm 4.2$ & $22.2 \pm 4.6^{* *}$ & $27.8 \pm 1.5^{* *}$ & - & - \\
\hline $\mathrm{H}_{2} \mathrm{O}$-eluted fraction & $0.0 \pm 4.9$ & $5.3 \pm 3.1$ & $8.9 \pm 3.0$ & $10.5 \pm 5.9$ & $13.5 \pm 4.9$ & $27.7 \pm 1.8 * *$ & - \\
\hline \multirow[t]{2}{*}{ Sample } & \multicolumn{6}{|c|}{ Cell viability (\%) } & \multirow[t]{2}{*}{$\overline{\mathrm{IC}_{50}(\mu \mathrm{g} / \mathrm{mL})}$} \\
\hline & $0 \mu \mathrm{g} / \mathrm{mL}$ & $1 \mu \mathrm{g} / \mathrm{mL}$ & $3 \mu \mathrm{g} / \mathrm{mL}$ & $10 \mu \mathrm{g} / \mathrm{mL}$ & $30 \mu \mathrm{g} / \mathrm{mL}$ & $100 \mu \mathrm{g} / \mathrm{mL}$ & \\
\hline $\mathrm{MeOH}$ extract & $100.0 \pm 2.5$ & $106.0 \pm 2.2$ & $103.1 \pm 2.1$ & $96.6 \pm 1.8$ & $96.9 \pm 3.2$ & $107.8 \pm 3.4$ & - \\
\hline $\mathrm{MeOH}$-eluted fraction & $100.0 \pm 3.6$ & $95.1 \pm 3.4$ & $98.5 \pm 2.8$ & $96.7 \pm 1.5$ & $80.1 \pm 0.6^{* *}$ & $42.8 \pm 1.3^{* *}$ & 80.5 \\
\hline $\mathrm{H}_{2} \mathrm{O}$-eluted fraction & $100.0 \pm 4.1$ & $97.6 \pm 3.6$ & $101.0 \pm 0.6$ & $102.5 \pm 1.0$ & $97.2 \pm 3.8$ & $101.6 \pm 2.7$ & - \\
\hline
\end{tabular}

Each value represents the mean \pm standard error of the mean $(\mathrm{SEM})(N=4)$

$* *$ Significantly different from the control group at $p<0.01$ 
Table 3 Inhibitory effects of anthracenone glycosides 1-4 and $\beta$-arbutin at different concentrations on melanogenesis and cell viability in B16 melanoma 4A5 cells

\begin{tabular}{|c|c|c|c|c|c|c|c|}
\hline \multirow[t]{2}{*}{ Sample } & \multicolumn{6}{|c|}{ Inhibition (\%) } & \multirow[t]{2}{*}{$\mathrm{IC}_{50}(\mu \mathrm{M})$} \\
\hline & $0 \mu \mathrm{M}$ & $0.01 \mu \mathrm{M}$ & $0.03 \mu \mathrm{M}$ & $0.1 \mu \mathrm{M}$ & $0.3 \mu \mathrm{M}$ & $1 \mu \mathrm{M}$ & \\
\hline 1 & $0.0 \pm 4.0$ & $17.5 \pm 3.4 * *$ & $21.5 \pm 2.7 * *$ & $31.9 \pm 2.1 * *$ & $45.1 \pm 0.4 * *$ & - & - \\
\hline 2 & $0.0 \pm 4.1$ & $8.8 \pm 4.0$ & $17.2 \pm 4.0^{*}$ & $19.6 \pm 5.3^{*}$ & $36.5 \pm 3.3^{* *}$ & - & - \\
\hline 3 & $0.0 \pm 1.1$ & $15.4 \pm 0.6^{* *}$ & $13.2 \pm 3.9^{*}$ & $21.2 \pm 3.8 * *$ & $22.0 \pm 2.2 * *$ & $24.7 \pm 1.1^{* *}$ & - \\
\hline 4 & $0.0 \pm 3.9$ & $12.2 \pm 4.5$ & $16.4 \pm 3.4^{*}$ & $15.9 \pm 1.9^{*}$ & $8.5 \pm 3.5$ & $16.8 \pm 2.4^{* *}$ & - \\
\hline \multirow[t]{2}{*}{ Sample } & \multicolumn{6}{|c|}{ Inhibition (\%) } & \multirow[t]{2}{*}{$\mathrm{IC}_{50}(\mu \mathrm{M})$} \\
\hline & $0 \mu \mathrm{M}$ & $10 \mu \mathrm{M}$ & $30 \mu \mathrm{M}$ & $100 \mu \mathrm{M}$ & $300 \mu \mathrm{M}$ & $1000 \mu \mathrm{M}$ & \\
\hline$\beta$-Arbutin & $0.0 \pm 1.9$ & $12.5 \pm 1.4$ & $12.3 \pm 4.7$ & $32.1 \pm 2.4 * *$ & $53.2 \pm 3.3^{* *}$ & - & 262 \\
\hline \multirow[t]{2}{*}{ Sample } & \multicolumn{6}{|c|}{ Cell viability (\%) } & \multirow[t]{2}{*}{$\mathrm{IC}_{50}(\mu \mathrm{M})$} \\
\hline & $0 \mu \mathrm{M}$ & $0.01 \mu \mathrm{M}$ & $0.03 \mu \mathrm{M}$ & $0.1 \mu \mathrm{M}$ & $0.3 \mu \mathrm{M}$ & $1 \mu \mathrm{M}$ & \\
\hline 1 & $100.0 \pm 0.8$ & $101.8 \pm 1.9$ & $101.8 \pm 1.7$ & $104.7 \pm 1.9$ & $94.7 \pm 3.2$ & $27.0 \pm 2.1 * *$ & 0.75 \\
\hline 2 & $100.0 \pm 1.8$ & $104.6 \pm 1.3$ & $103.3 \pm 1.1$ & $100.4 \pm 2.7$ & $91.9 \pm 1.1^{*}$ & $29.0 \pm 1.4 * *$ & 0.75 \\
\hline 3 & $100.0 \pm 1.0$ & $104.5 \pm 0.9$ & $102.6 \pm 0.8$ & $103.5 \pm 0.8$ & $102.4 \pm 0.8$ & $99.5 \pm 0.8$ & - \\
\hline 4 & $100.0 \pm 1.3$ & $102.0 \pm 1.1$ & $104.0 \pm 3.6$ & $102.1 \pm 2.0$ & $101.1 \pm 1.1$ & $100.5 \pm 1.0$ & - \\
\hline \multirow[t]{2}{*}{ Sample } & \multicolumn{6}{|c|}{ Cell viability (\%) } & \multirow[t]{2}{*}{$\mathrm{IC}_{50}(\mu \mathrm{M})$} \\
\hline & $0 \mu \mathrm{M}$ & $10 \mu \mathrm{M}$ & $30 \mu \mathrm{M}$ & $100 \mu \mathrm{M}$ & $300 \mu \mathrm{M}$ & $1000 \mu \mathrm{M}$ & \\
\hline$\beta$-Arbutin & $100.0 \pm 2.2$ & $93.5 \pm 2.3$ & $86.9 \pm 2.8$ & $87.9 \pm 2.6$ & $81.1 \pm 1.2$ & $46.1 \pm 2.2^{* *}$ & 902 \\
\hline
\end{tabular}

Each value represents the mean $\pm \operatorname{SEM}(N=4)$

*, ** Significantly different from the control group at $* p<0.05$ and $* * p<0.01$

Table 4 Effects of auriculataosides A (1) and B (2) at different concentrations on cell viability in human dermal fibroblasts

\begin{tabular}{llllllll}
\hline Sample & \multicolumn{2}{l}{ Cell viability $(\%)$} & \multirow{2}{*}{$\mathrm{IC}_{50}(\mu \mathrm{M})$} \\
\cline { 2 - 6 } & $0 \mu \mathrm{M}$ & $0.01 \mu \mathrm{M}$ & $0.03 \mu \mathrm{M}$ & $0.1 \mu \mathrm{M}$ & $0.3 \mu \mathrm{M}$ & $1 \mu \mathrm{M}$ & \\
\hline $\mathbf{1}$ & $100.0 \pm 6.7$ & $99.7 \pm 6.4$ & $99.7 \pm 5.6$ & $92.0 \pm 3.3$ & $95.6 \pm 6.6$ & $93.8 \pm 6.2$ & - \\
$\mathbf{2}$ & $100.0 \pm 5.0$ & $96.0 \pm 4.0$ & $93.7 \pm 3.9$ & $97.0 \pm 1.6$ & $92.9 \pm 3.8$ & $95.3 \pm 3.9$ & - \\
\hline
\end{tabular}

Each value represents the mean $\pm \operatorname{SEM}(N=4)$ compounds $\mathbf{1}$ and $\mathbf{2}$, we examined the autoxidation inhibitory effects of $\mathbf{1}$ and $\mathbf{2}$ after dopachrome synthesis in the concentration range of 0.01 to $100 \mu \mathrm{M}$; ascorbic acid was used as the positive control [35]. Compounds $\mathbf{1}$ and $\mathbf{2}$ did not show significant inhibitory effects. On the contrary, they did show autoxidation-promoting effects at a high concentration $(100 \mu \mathrm{M})($ Table 7$)$. Nevertheless, we believe that the color of the test sample may have affected the results at higher concentrations.

\section{Effects of 1 and 2 on microphthalmia-associated transcription factor, tyrosinase, TRP-1, and TRP-2 protein expression levels}

In human and mouse, intracellular signal transduction is activated by increasing cAMP expression through UV irradiation or stimulation, such as $\alpha-\mathrm{MSH}$, which activates microphthalmia-associated transcription factor (MITF). mRNA transcription and translation of target proteins, such as tyrosinase, are promoted, and then melanin is produced [2]. Therefore, in order to investigate the mechanism of action underlying melanogenesis inhibition, we examined the effects of compounds $\mathbf{1}$ and $\mathbf{2}$ on the production of tyrosinase, MITF, TRP-1, and TRP-2, which are important proteins involved in melanin production, under theophylline-stimulated conditions in B16 melanoma 4A5 cells. $\beta$-Actin was used as the loading control. Expression levels of MITF, tyosinase, TRP-1, and TRP-2 after treatment with $0.3 \mu \mathrm{M}$ of compounds $\mathbf{1}$ and $\mathbf{2}$ were 56 and $39 \%$, 43 and $60 \%, 46$ and $40 \%$, and 48 and $37 \%$, respectively. Namely, decreases in MITF, tyrosinase, TRP-1, and TRP-2 protein expression levels were observed after treatment with 1 and 2 in the concentration range of 0.1 to $0.3 \mu \mathrm{M}$ (Fig. 3, ESM Fig. S3). These findings suggest that the 
Table 5 Effects of anthracenone glycosides 1-4, kojic acid, and $\beta$-arbutin at different concentrations on mushroom tyrosinase activity

\begin{tabular}{|c|c|c|c|c|c|c|c|}
\hline \multirow[t]{2}{*}{ Sample } & \multicolumn{6}{|c|}{ Inhibition (\%) } & \multirow[t]{2}{*}{$\mathrm{IC}_{50}(\mu \mathrm{M})$} \\
\hline & $0 \mu \mathrm{M}$ & $0.01 \mu \mathrm{M}$ & $0.1 \mu \mathrm{M}$ & $1 \mu \mathrm{M}$ & $10 \mu \mathrm{M}$ & $100 \mu \mathrm{M}$ & \\
\hline 1 & $0.0 \pm 2.7$ & $-3.5 \pm 0.7$ & $-3.1 \pm 2.0$ & $-2.0 \pm 2.4$ & $-1.7 \pm 2.6$ & $-2.2 \pm 2.0$ & - \\
\hline 2 & $0.0 \pm 2.9$ & $-2.2 \pm 0.9$ & $-1.4 \pm 1.5$ & $0.5 \pm 1.1$ & $0.2 \pm 0.9$ & $0.2 \pm 1.0$ & - \\
\hline 3 & $0.0 \pm 0.8$ & $-1.1 \pm 1.5$ & $-0.5 \pm 1.6$ & $-0.1 \pm 1.8$ & $2.3 \pm 2.9$ & $3.2 \pm 1.0$ & - \\
\hline 4 & $0.0 \pm 2.4$ & $-3.0 \pm 1.3$ & $-0.1 \pm 1.6$ & $0.4 \pm 1.7$ & $3.2 \pm 3.7$ & $2.2 \pm 1.5$ & - \\
\hline \multirow[t]{2}{*}{ Sample } & \multicolumn{6}{|c|}{ Inhibition (\%) } & \multirow[t]{2}{*}{$\mathrm{IC}_{50}(\mu \mathrm{M})$} \\
\hline & $0 \mu \mathrm{M}$ & $1 \mu \mathrm{M}$ & $3 \mu \mathrm{M}$ & $10 \mu \mathrm{M}$ & $30 \mu \mathrm{M}$ & $100 \mu \mathrm{M}$ & \\
\hline Kojic acid & $0.0 \pm 1.7$ & $12.4 \pm 4.9$ & $20.8 \pm 2.6^{* *}$ & $41.1 \pm 2.7^{* *}$ & $63.7 \pm 1.4^{* *}$ & $85.4 \pm 0.5^{* *}$ & 15.5 \\
\hline \multirow[t]{2}{*}{ Sample } & \multicolumn{6}{|c|}{ Inhibition (\%) } & \multirow[t]{2}{*}{$\mathrm{IC}_{50}(\mu \mathrm{M})$} \\
\hline & $0 \mu \mathrm{M}$ & $10 \mu \mathrm{M}$ & $30 \mu \mathrm{M}$ & $100 \mu \mathrm{M}$ & $300 \mu \mathrm{M}$ & $1000 \mu \mathrm{M}$ & \\
\hline$\beta$-Arbutin & $0.0 \pm 1.3$ & $1.3 \pm 2.6$ & $3.8 \pm 1.2$ & $6.6 \pm 1.5^{*}$ & $10.2 \pm 0.6^{* *}$ & $20.6 \pm 1.4^{* *}$ & - \\
\hline
\end{tabular}

Each value represents the mean $\pm \operatorname{SEM}(N=4)$

*, **Significantly different from the control group at $* p<0.05$ and $* * p<0.01$

Table 6 Effects of anthracenone glycosides 1-4, kojic acid, and $\beta$-arbutin at different concentrations on melanoma tyrosinase activity

\begin{tabular}{|c|c|c|c|c|c|c|c|}
\hline \multirow[t]{2}{*}{ Sample } & \multicolumn{6}{|c|}{ Inhibition (\%) } & \multirow[t]{2}{*}{$\mathrm{IC}_{50}(\mu \mathrm{M})$} \\
\hline & $0 \mu \mathrm{M}$ & $0.01 \mu \mathrm{M}$ & $0.03 \mu \mathrm{M}$ & $0.1 \mu \mathrm{M}$ & $0.3 \mu \mathrm{M}$ & $1 \mu \mathrm{M}$ & \\
\hline 1 & $0.0 \pm 0.4$ & $-0.6 \pm 0.6$ & $-2.7 \pm 1.3$ & $-2.8 \pm 1.0$ & $-0.1 \pm 1.1$ & $-0.8 \pm 1.3$ & - \\
\hline 2 & $0.0 \pm 1.8$ & $-0.9 \pm 0.8$ & $-0.3 \pm 0.7$ & $1.5 \pm 0.5$ & $-2.2 \pm 1.0$ & $-5.6 \pm 0.6$ & - \\
\hline 3 & $0.0 \pm 1.4$ & $-5.4 \pm 1.2$ & $-8.1 \pm 3.5$ & $-10.3 \pm 0.6$ & $-9.5 \pm 0.6$ & $-9.8 \pm 0.8$ & - \\
\hline 4 & $0.0 \pm 0.9$ & $-1.9 \pm 1.7$ & $-1.3 \pm 0.3$ & $-5.0 \pm 0.7$ & $-2.5 \pm 1.5$ & $-6.4 \pm 2.4$ & - \\
\hline \multirow[t]{2}{*}{ Sample } & \multicolumn{6}{|c|}{ Inhibition (\%) } & \multirow[t]{2}{*}{$\mathrm{IC}_{50}(\mu \mathrm{M})$} \\
\hline & $0 \mu \mathrm{M}$ & $1 \mu \mathrm{M}$ & $3 \mu \mathrm{M}$ & $10 \mu \mathrm{M}$ & $30 \mu \mathrm{M}$ & $100 \mu \mathrm{M}$ & \\
\hline Kojic acid & $0.0 \pm 2.0$ & $-2.0 \pm 0.5$ & $-2.8 \pm 0.7$ & $-1.0 \pm 0.8$ & $-2.0 \pm 1.8$ & $-10.9 \pm 1.1$ & - \\
\hline \multirow[t]{2}{*}{ Sample } & \multicolumn{6}{|c|}{ Inhibition (\%) } & \multirow[t]{2}{*}{$\mathrm{IC}_{50}(\mu \mathrm{M})$} \\
\hline & $0 \mu \mathrm{M}$ & $10 \mu \mathrm{M}$ & $30 \mu \mathrm{M}$ & $100 \mu \mathrm{M}$ & $300 \mu \mathrm{M}$ & $1000 \mu \mathrm{M}$ & \\
\hline$\beta$-Arbutin & $0.0 \pm 0.6$ & $2.2 \pm 1.2$ & $6.1 \pm 1.6$ & $18.0 \pm 0.7 * *$ & $38.1 \pm 0.9 * *$ & $56.6 \pm 0.4 * *$ & 600 \\
\hline
\end{tabular}

Each value represents the mean $\pm \operatorname{SEM}(N=4)$

**Significantly different from the control group at $p<0.01$

inhibition of MITF, tyrosinase, TRP-1, and TRP-2 production is the main mechanism of action of $\mathbf{1}$ and $\mathbf{2}$. Further studies are warranted to clarify their effects on the upper signaling pathway of MITF.

\section{Conclusions}

Two new phlegmacin-type anthracenone dimer glycosides, here compounds $\mathbf{1}$ and $\mathbf{2}$, isolated from the seeds of $C$. auriculata were examined for melanogenesis inhibitory effects in B16 melanoma 4A5 cells under theophylline-stimulated conditions. Compounds $\mathbf{1}$ and $\mathbf{2}$ significantly inhibited melanin production in the concentration range of 0.03 to $0.3 \mu \mathrm{M}$. We suggest the inhibition of MITF, tyrosinase, TRP-1, and TRP-2 protein expression is part of their mechanism of action.

\section{Materials and methods}

\section{Instrumentation and material used to obtain physical data}

Optical rotations were measured using a SEPA-300 digital polarimeter $(l=0.5)$ (Horiba Ltd., Kyoto, Japan). 
Table 7 Effects of anthracenone glycosides 1-4 and ascorbic acid at different concentrations on autoxidation

\begin{tabular}{|c|c|c|c|c|c|c|c|}
\hline \multirow[t]{2}{*}{ Sample } & \multicolumn{6}{|c|}{ Inhibition (\%) } & \multirow[t]{2}{*}{$\mathrm{IC}_{50}(\mu \mathrm{M})$} \\
\hline & $0 \mu \mathrm{M}$ & $0.01 \mu \mathrm{M}$ & $0.1 \mu \mathrm{M}$ & $1 \mu \mathrm{M}$ & $10 \mu \mathrm{M}$ & $100 \mu \mathrm{M}$ & \\
\hline 1 & $0.0 \pm 5.8$ & $-3.1 \pm 6.7$ & $-10.6 \pm 6.6$ & $6.9 \pm 6.1$ & $3.1 \pm 5.8$ & $-36.8 \pm 6.2 * *$ & - \\
\hline 2 & $0.0 \pm 4.3$ & $-8.8 \pm 6.2$ & $-13.7 \pm 3.8$ & $-5.5 \pm 7.2$ & $-24.5 \pm 11.3$ & $-68.3 \pm 3.9 * *$ & - \\
\hline 3 & $0.0 \pm 10.6$ & $-3.7 \pm 9.4$ & $-10.7 \pm 11.2$ & $-13.3 \pm 10.9$ & $-6.8 \pm 9.0$ & $-10.4 \pm 5.9$ & - \\
\hline 4 & $0.0 \pm 11.2$ & $3.5 \pm 8.1$ & $-7.2 \pm 11.7$ & $-22.1 \pm 5.5$ & $-6.2 \pm 5.3$ & $-17.2 \pm 3.0$ & - \\
\hline \multirow[t]{2}{*}{ Sample } & \multicolumn{6}{|c|}{ Inhibition (\%) } & \multirow[t]{2}{*}{$\mathrm{IC}_{50}(\mu \mathrm{M})$} \\
\hline & $0 \mu \mathrm{M}$ & $1 \mu \mathrm{M}$ & $3 \mu \mathrm{M}$ & $10 \mu \mathrm{M}$ & $30 \mu \mathrm{M}$ & $100 \mu \mathrm{M}$ & \\
\hline Ascorbic acid & $0.0 \pm 3.3$ & $6.1 \pm 0.6$ & $15.0 \pm 1.6$ & $20.8 \pm 1.7 * *$ & $33.4 \pm 2.8 * *$ & $47.7 \pm 1.8^{* *}$ & ca. 100 \\
\hline
\end{tabular}

Each value represents the mean $\pm \operatorname{SEM}(N=4)$

**Significantly different from the control group at $p<0.01$

Fig. 3 Effects of auriculataosides A (1) and B (2) on microphthalmia-associated transcription factor (MITF), tyrosinase (TYR) and tyrosinase-related protein (TRP)-1, and TRP-2 protein levels

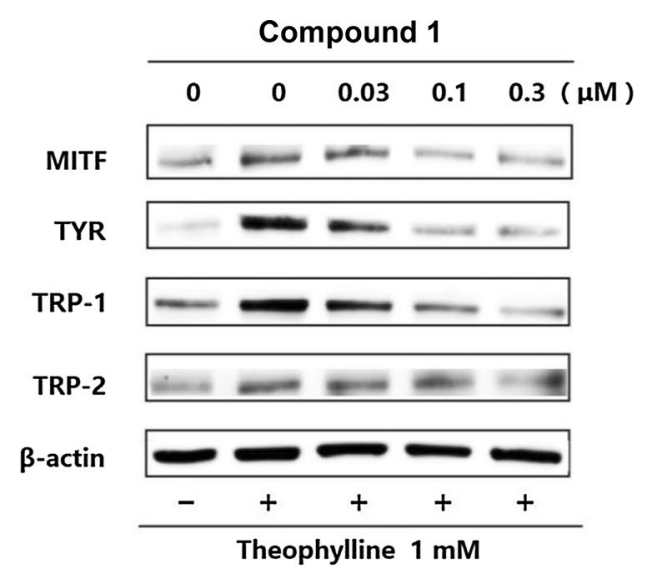

High-resolution mass spectrometry (high-resolution FABMS, EI-MS) and mass spectrometry (FAB-MS, EI-MS) were carried out using JMS-SX102 and JMS-GCMATE mass spectrometers (JEOL Ltd., Tokyo, Japan). The IR absorption spectrum was measured using a FT-IR DR-8000 spectrometer (Shimadzu Corp., Kyoto, Japan). The UV absorption spectrum was measured using a UV-1600 spectrometer (Shimadzu Corp.). The CD spectrum was measured using a J-1500 circular dichroism spectrometer (JASCO Corp., Tokyo, Japan). JEOL EX-270 (270 MHz), JNM-LA $500(500 \mathrm{MHz})$, and JNM-ECA $600 \mathrm{~K}(600 \mathrm{MHz})$ instruments (all JEOL Ltd.) were used for ${ }^{1} \mathrm{H}-\mathrm{NMR}$ and ${ }^{13} \mathrm{C}-\mathrm{NMR}$ measurements, and tetramethylsilane (TMS) was used as the internal standard. For HPLC, a LC-6AD pump, RID-10A differential refractive index detector, and SPD-10A UV-Vis detector were used (Shimadzu Corp.).

Silica Gel 60 N (Kanto Chemical Co., Inc., Tokyo, Japan) was used as the normal-phase adsorbent for column chromatography, and Chromatorex ODS DM 1020 T (Fuji Silicia; Fuji Silysia Chemica, Kasugai, Japan) was used as the reversed-phase system. For TLC, we used silica gel $60 \mathrm{~F}_{254}$ (normal phase; Merck KGaA, Darmstadt, Germany), RP-18
$60 \mathrm{~F}_{254}$ (reversed phase; Merck KGaA), silica gel $60 \mathrm{~F}_{254}$ HPTLC (normal phase; Merck KGaA), and RP-18 $\mathrm{WF}_{254}$ HPTLC (reversed phase; Merck KGaA). Spot detection was carried out by UV irradiation (254 $\mathrm{nm}$ ) and spraying $1 \%$ $\mathrm{Ce}\left(\mathrm{SO}_{4}\right) / 10 \% \mathrm{H}_{2} \mathrm{SO}_{4}$ aqueous solution followed by heating. Reagents (special grade) purchased from Wako Pure Chemical Industries, Ltd (Osaka, Japan). were used unless otherwise specified.

\section{Plant material}

The seeds of $C$. auriculata cultivated in India were purchased from NTH India Pvt. Ltd. (Gurgaon, India) in 2009 and identified by one of the authors (MY). A voucher specimen is kept in our laboratory (KPU-N.T.H. CAS-1).

\section{Extraction and isolation}

The seeds of $C$. auriculata (3929 g) were crushed and extracted three times with $\mathrm{MeOH}$ under reflux for $3 \mathrm{~h}$. Evaporation of the solvent under reduced pressure provided a $\mathrm{MeOH}$ extract $(430.6 \mathrm{~g}, 10.96 \%)$. A part of the $\mathrm{MeOH}$ 
extract (399.0 g) suspended in $\mathrm{H}_{2} \mathrm{O}$ was extracted with $n$-hexane to furnish an $n$-hexane-soluble fraction $(46.4 \mathrm{~g}$, $1.27 \%$ ) and $\mathrm{a}_{2} \mathrm{O}$-soluble fraction (350.8 g, 9.63\%). A part of the $\mathrm{H}_{2} \mathrm{O}$-soluble fraction ( $322.7 \mathrm{~g}$ ) was subjected to Diaion HP-20 column chromatography $\left(\mathrm{H}_{2} \mathrm{O} \rightarrow \mathrm{MeOH}\right)$ to give the $\mathrm{H}_{2} \mathrm{O}$-eluted fraction $(248.2 \mathrm{~g}, 7.41 \%)$ and the $\mathrm{MeOH}$-eluted fraction $(63.2 \mathrm{~g}, 1.89 \%)$, respectively. The $\mathrm{MeOH}-$ eluted fraction $(60.0 \mathrm{~g})$ was subjected to normal-phase silica gel column chromatography $[1.5 \mathrm{~kg}$, $\mathrm{CHCl}_{3} \rightarrow \mathrm{CHCl}_{3}: \mathrm{MeOH}(20: 1, \mathrm{v} / \mathrm{v}) \rightarrow \mathrm{CHCl}_{3}: \mathrm{MeOH}: \mathrm{H}_{2} \mathrm{O}$ $(10: 3: 1 \rightarrow 7: 3: 1 \rightarrow 6: 4: 1, \mathrm{v} / \mathrm{v} / \mathrm{v}) \rightarrow \mathrm{MeOH}]$ to give nine fractions (Fr.) [ Fr. $1(0.2$ g), Fr. $2(3.0$ g), Fr. $3(2.7$ g), Fr. 4 $(0.6$ g), Fr. 5 (10.4 g), Fr. 6 (5.7 g), Fr. 7 (16.7 g), Fr. 8 $(16.3$ g), Fr. $9(0.9$ g)].

Fr. $5(10.4 \mathrm{~g})$ was further separated by ODS column chromatography [ $300 \mathrm{~g}, \mathrm{MeOH}: \mathrm{H}_{2} \mathrm{O}(20: 80 \rightarrow 30: 70 \rightarrow 40: 60 \rightarrow$ $50: 50 \rightarrow 60: 40 \rightarrow 70: 30 \rightarrow 80: 20, \mathrm{v} / \mathrm{v}) \rightarrow \mathrm{MeOH}]$ to give 13 fractions [Fr. 5-1 to 5-4, Fr. 5-5 (1991 mg), Fr. 5-6 (588 mg), Fr. 5-7, Fr. 5-8 (609 mg), Fr. 5-9 (269 mg), Fr. 5-10 (820 mg), Fr. 5-11 to 5-13]. Fr. 5-5 (1991 mg) was separated and purified by HPLC $\left[\mathrm{MeOH}: \mathrm{H}_{2} \mathrm{O}(45: 55\right.$ and 40:60, v/v) or $\left.\mathrm{CH}_{3} \mathrm{CN}: \mathrm{MeOH}: \mathrm{H}_{2} \mathrm{O}(19: 8: 73, \mathrm{v} / \mathrm{v} / \mathrm{v})\right]$ to give rumejaposide $\mathrm{E}(\mathbf{3}, 6.6 \mathrm{mg}, 0.00021 \%)$ and rumejaposide $\mathrm{F}$ $(4,6.1 \mathrm{mg}, 0.00019 \%)$. Fr. 5-6 (588 mg) was also subjected to $\mathrm{HPLC}\left[\mathrm{MeOH}: \mathrm{H}_{2} \mathrm{O}(45: 55, \mathrm{v} / \mathrm{v})\right]$ to give rumejaposide $\mathrm{E}(\mathbf{3}, 17.7 \mathrm{mg}, 0.00056 \%)$ and rumejaposide $\mathrm{F}(\mathbf{4}, 18.1 \mathrm{mg}$, $0.00057 \%)$. Fr. 5-8 (609 mg) was subjected to silica gel column chromatography $\left[\mathrm{CHCl}_{3} \rightarrow \mathrm{CHCl}_{3}: \mathrm{MeOH}(20: 1\right.$, $\mathrm{v} / \mathrm{v}) \rightarrow \mathrm{CHCl}_{3}: \mathrm{MeOH}: \mathrm{H}_{2} \mathrm{O}(10: 3: 1, \mathrm{v} / \mathrm{v} / \mathrm{v}$, lower layer)] and HPLC [MeOH: $\left.\mathrm{H}_{2} \mathrm{O}(32: 68, \mathrm{v} / \mathrm{v})\right]$ to give auriculataoside A (1, $240.4 \mathrm{mg}, 0.0076 \%)$. Fr. 5-9 (269 mg) was separated by HPLC [MeOH: $\left.\mathrm{H}_{2} \mathrm{O}(70: 30, \mathrm{v} / \mathrm{v})\right]$ to furnish auriculataoside A (1, $25.6 \mathrm{mg}, 0.00081 \%)$ and auriculataoside B (2, $57.9 \mathrm{mg}, 0.0018 \%)$. Fr. 5-10 (400 mg) was purified by HPLC [MeOH: $\left.\mathrm{H}_{2} \mathrm{O}(75: 25, \mathrm{v} / \mathrm{v})\right]$ to obtain auriculataoside B (2, $142.0 \mathrm{mg}, 0.0092 \%)$.

\section{Auriculataoside A (1)}

Red powder; $[\alpha]_{\mathrm{D}}^{24}-129.5(c=0.20,1,4$-dioxane $) ; \mathrm{UV}$ $(\mathrm{MeOH}) \lambda_{\max }(\log \varepsilon) 225$ (4.58), 273 (4.71), 399 (4.09), 433 (4.02) nm; CD $(\mathrm{MeOH}) \mathrm{nm}(\Delta \varepsilon) 217(+49.0), 234(-17.2)$, 242 (-6.7), $270(-38.0), 284(+25.5)$; IR (KBr) $v_{\max } 3450$, $2948,1655,1070 \mathrm{~cm}^{-1}$; ${ }^{1} \mathrm{H}-\mathrm{NMR}$ (DMSO- $d_{6}, 500 \mathrm{MHz}$ ) $1.15,2.24\left(3 \mathrm{H}\right.$ each, both s, $\left.\mathrm{CH}_{3}-3^{\prime}, 3\right), 2.61(2 \mathrm{H}$, br s, $\left.\mathrm{H}_{2}-4^{\prime}\right)$, 2.74, 2.88 (1H each, both $\left.\mathrm{d}, J=16.8 \mathrm{~Hz}, \mathrm{H}-2^{\prime}\right), 3.21$ (1H, m, H-4"), 3.35 (1H, m, H-3"), 3.43 (1H, m, H-5"), 3.47 $\left(1 \mathrm{H}, \mathrm{m}, \mathrm{H}-2^{\prime \prime}\right), 3.48$ (1H, m, H-6"a), 3.65, 3.89 (3H each, both s, $\left.\mathrm{OCH}_{3}-6^{\prime}, 6\right), 3.74\left(1 \mathrm{H}, \mathrm{dd}, J=11.2,5.5 \mathrm{~Hz}, \mathrm{H}-6^{\prime \prime} \mathrm{b}\right)$, $4.79\left(1 \mathrm{H}\right.$, br s, $\left.\mathrm{OH}-3^{\prime}\right), 5.04\left(1 \mathrm{H}, \mathrm{d}, J=7.7 \mathrm{~Hz}, \mathrm{H}-1^{\prime \prime}\right), 6.20$, $6.88\left(1 \mathrm{H}\right.$ each, both $\left.\mathrm{d}, J=2.1 \mathrm{~Hz}, \mathrm{H}-5^{\prime}, 7^{\prime}\right), 7.22,7.59(1 \mathrm{H}$ each, both br s, H-2, 4), $7.55(1 \mathrm{H}, \mathrm{s}, \mathrm{H}-5), 11.88(1 \mathrm{H}, \mathrm{br} \mathrm{s}$, $\mathrm{OH}-1), 12.19(1 \mathrm{H}$, br s, $\mathrm{OH}-8), 19.20\left(1 \mathrm{H}\right.$, br s, $\left.\mathrm{OH}-9^{\prime}\right)$;
${ }^{13} \mathrm{C}-\mathrm{NMR}$ data, see Table 1; positive-ion FAB-MS $\mathrm{m} / z 755$ $[\mathrm{M}+\mathrm{Na}]^{+}$; high-resolution (HR)FAB-MS: $\mathrm{m} / \mathrm{z} 755.1958$ (calculated for $\mathrm{C}_{38} \mathrm{H}_{36} \mathrm{O}_{15}[\mathrm{M}+\mathrm{Na}]^{+}, 755.1952$ ).

\section{Auriculataoside B (2)}

Red powder; $[\alpha]_{\mathrm{D}}^{24}-41.3(c=0.28,1,4$-dioxane $) ; \mathrm{UV}$ $(\mathrm{MeOH}) \lambda_{\max }(\log \varepsilon) 225$ (4.62), 273 (4.74), 399 (3.72), $433(4.05) \mathrm{nm} ; \mathrm{CD}(\mathrm{MeOH}) \mathrm{nm}(\Delta \varepsilon) 217(-42.8), 233$ $(+20.5), 268(+23.8), 282(-33.9) ; \mathrm{IR}(\mathrm{KBr}) v_{\max } 3450$, 2948, $1655,1070 \mathrm{~cm}^{-1} ;{ }^{1} \mathrm{H}-\mathrm{NMR}$ (DMSO- $d_{6}, 500 \mathrm{MHz}$ ) $1.18,2.24$ (3H each, both s, $\left.\mathrm{CH}_{3}-3^{\prime}, 3\right), 2.57,2.75(1 \mathrm{H}$ each, both d, $\left.J=16.2 \mathrm{~Hz}, \mathrm{H}_{2}-4^{\prime}\right), 2.72,2.90$ (1H each, both $\left.\mathrm{d}, J=16.8 \mathrm{~Hz}, \mathrm{H}_{2}-2^{\prime}\right), 3.22\left(1 \mathrm{H}, \mathrm{m}, \mathrm{H}-4^{\prime \prime}\right), 3.35(1 \mathrm{H}, \mathrm{m}$, H-3"), 3.44 (1H, m, H-5"), 3.47 (1H, m, H-2"), $3.50(1 \mathrm{H}$, m, H-6"a), 3.66, 3.85 (3H each, both s, $\mathrm{OCH}_{3}-6^{\prime}, 6$ ), 3.75 $\left(1 \mathrm{H}, \mathrm{dd}, J=11.6,5.5 \mathrm{~Hz}, \mathrm{H}-6^{\prime \prime} \mathrm{b}\right), 4.78\left(1 \mathrm{H}, \mathrm{br} \mathrm{s}, \mathrm{OH}-3^{\prime}\right)$, $5.02\left(1 \mathrm{H}, \mathrm{d}, J=7.7 \mathrm{~Hz}, \mathrm{H}-1^{\prime \prime}\right), 6.20,6.89(1 \mathrm{H}$ each, br s, H-5', 7'), 7.18, 7.53 (1H each, both br s, H-2, 4), $7.52(1 \mathrm{H}, \mathrm{s}$, H-5), 11.90 (1H, br s, OH-1), 12.27 (1H, br s, OH-8), 19.20 $\left(1 \mathrm{H}\right.$, br s, $\left.\mathrm{OH}-\mathrm{9}^{\prime}\right) ;{ }^{13} \mathrm{C}-\mathrm{NMR}$ data, see Table 1; positive-ion FAB-MS $m / z, 755[\mathrm{M}+\mathrm{Na}]^{+}$; HRFAB-MS: $m / z 755.1952$ (calculated for $\mathrm{C}_{38} \mathrm{H}_{36} \mathrm{O}_{15}[\mathrm{M}+\mathrm{Na}]^{+}, 755.1952$ ).

\section{Acid hydrolysis and monosaccharide identification of 1 and} 2

Compounds 1 and 2 ( $1 \mathrm{mg}$ each) were mixed with $1.0 \mathrm{M} \mathrm{HCl}$ $(1.0 \mathrm{~mL})$ and each solution was refluxed for $3 \mathrm{~h}$. The reaction mixture was immersed in ice-cold water and neutralized with Amberlite IRA-400 ( $\mathrm{OH}^{-}$form), and the resin was removed by filtration. After extraction with EtOAc, the aqueous layer was analyzed by HPLC [HPLC column, Kaseisorb LC $\mathrm{NH}_{2}-60-5,4.6 \mathrm{~mm}$ i.d. $\times 250 \mathrm{~mm}$ (Tokyo Kasei Co., Ltd., Tokyo, Japan); detection: optical mobile phase, $\mathrm{CH}_{3} \mathrm{CN}-\mathrm{H}_{2} \mathrm{O}(85: 15$, v/v); flow rate: $0.80 \mathrm{~mL} / \mathrm{min}$; column temperature: room temperature] equipped with an optical rotation detector (Shodex OR-2; Showa Denko K.K., Tokyo, Japan). D-glucose (from 1 and 2) was confirmed by comparing its retention time $\left(t_{\mathrm{R}}\right)$ and optical rotation with those of an authentic sample; $t_{\mathrm{R}}=11.5 \mathrm{~min}$ (D-glucose, positive optical rotation).

\section{Bioassay methods}

\section{Reagents}

Dulbecco's modified Eagle's medium (DMEM, 4500 mg/L glucose) was purchased from Sigma-Aldrich (St. Louis, MO, USA); fetal bovine serum (FBS). Penicillin, and streptomycin were purchased from Gibco (Invitrogen, Carlsbad, CA, USA). The tetrazolium salt MTT was obtained from Dojindo Laboratories (Kumamoto, Japan); Soluene-350 was obtained 
from PerkinElmer, Inc. (Waltham, MA, USA); Blocking One was from Nacalai Tesque (Kyoto, Japan); phosphatase inhibitor was purchased from Roche (Mannheim, Germany); proteinase inhibitor, the Protein Assay kit, and other chemicals were purchased from Wako Pure Chemical Industries, Ltd. Six- and 24-well multiwell plates and 96-well microplates were purchased from Greiner Japan (Tokyo, Japan).

\section{Cell culture}

Murine B16 melanoma 4A5 cells (RCB0557) were obtained from Riken Cell Bank (Tsukuba, Japan) and HDF (code no. CA10605n) were purchased from Toyobo Co., Ltd. (Tokyo, Japan). The B16 melanoma 4A5 cells were grown in DMEM (4500 mg/L glucose) medium (Sigma-Aldrich) containing $10 \% \mathrm{FBS}, 100 \mathrm{units} / \mathrm{mL}$ penicillin, and $100 \mu \mathrm{g} / \mathrm{mL}$ streptomycin under conditions of $5 \% \mathrm{CO}_{2}$ and $37{ }^{\circ} \mathrm{C}$. The $\mathrm{HDF}$ cells were grown in DMEM (1000 mg/L glucose) medium. Cells were harvested by incubation in phosphate-buffered saline (PBS) containing $1 \mathrm{mM}$ EDTA and $0.25 \%$ trypsin for approximately $5 \mathrm{~min}$ at $37^{\circ} \mathrm{C}$ and were used for subsequent bioassays.

\section{Effects on melanogenesis}

Melanin production The screening test for melanogenesis using B16 melanoma 4A5 cells was performed as described previously [23]. B16 melanoma 4A5 cells $\left(2.0 \times 10^{4}\right.$ cells $/ 400 \mu \mathrm{L} /$ well) were seeded in a 24 -well multiwell plate and pre-cultured for $24 \mathrm{~h}\left(5 \% \mathrm{CO}_{2}, 37^{\circ} \mathrm{C}\right)$, following which the test sample and theophylline (as melanogenesis stimulator; final concentration $1 \mathrm{mM}$ ) were added. After culturing for $72 \mathrm{~h}$, the cells were detached and recovered by trypsin treatment, washed with PBS, and dissolved in $\mathrm{NaOH}$ aq. $\left(120 \mu \mathrm{L} /\right.$ well, $\left.80^{\circ} \mathrm{C}, 15 \mathrm{~min}\right)$. The cell lysate was fractionated $(100 \mu \mathrm{L} /$ well $)$ in a 96 -well microplate, and the absorbance of melanin produced was measured with a microplate reader (SH-1000; Corona Electric Co. Ltd., Hitachinaka, Japan) (wavelength $405 \mathrm{~nm}$ ). The test sample was dissolved in DMSO and added to the medium (final concentration of DMSO 0.1\%). Inhibition was measured as:

Inhibition $(\%)=\{[A-B /(C / 100)] / A\} \times 100$

where $A$ is the absorbance without test sample (control); $B$ is the absorbance with test sample; $C$ is cell viability (\%) with test sample.

Cell viability B16 melanoma 4A5 cells $\left(5.0 \times 10^{3}\right.$ cells $/ 100$ $\mu \mathrm{L} /$ well $)$ and $\mathrm{HDF}\left(5.0 \times 10^{3}\right.$ cells $/ 100 \mu \mathrm{L} /$ well $)$ were seeded in a 96-well microplate and pre-cultured for $24 \mathrm{~h}\left(5 \% \mathrm{CO}_{2}\right.$, $37^{\circ} \mathrm{C}$ ), following which the test sample and theophylline (final concentration $1 \mathrm{mM}$ ) were added. After culturing for $71 \mathrm{~h}(5 \%$ $\left.\mathrm{CO}_{2}, 37{ }^{\circ} \mathrm{C}\right), 10 \mu \mathrm{L}$ of MTT $(0.5 \%)$ was added. After incuba- tion for $1 \mathrm{~h}\left(5 \% \mathrm{CO}_{2}, 37{ }^{\circ} \mathrm{C}\right)$, the formazan present, which was produced as a catalytic product of MTT, was dissolved in $100 \mu \mathrm{L}$ of 2-propanol containing $0.04 \mathrm{M} \mathrm{HCl}$, and the absorbance was measured with a microplate reader (SH-1000; Corona Electric Co. Ltd.; measurement wavelength $570 \mathrm{~nm}$, reference wavelength $655 \mathrm{~nm}$ ). The test sample was dissolved in DMSO and added to the medium (final concentration of DMSO $0.1 \%$ ). Viability of the cells was measured as:

Viability $(\%)=1-[(A-B) / A] \times 100$

where $A$ is the absorbance without test sample (control); $B$ is the absorbance with test sample.

\section{Effects on mushroom tyrosinase activity}

Inhibitory effects on mushroom tyrosinase activity were examined as reported elsewhere [9,31]. A phosphate buffer solution (pH 6.5) containing $2.5 \mathrm{mM}$ L-DOPA was dispensed into a 96-well microplate in the amount of $70 \mu \mathrm{L} /$ well, and $20 \mu \mathrm{L}$ of test sample (DMSO solution) was added. Next, $120 \mu \mathrm{L} /$ well of a phosphate buffer solution ( 80 units $/ \mathrm{mL}$ ) of mushroom-derived tyrosinase was added to each well to induce the enzymatic reaction $\left(25^{\circ} \mathrm{C}, 5 \mathrm{~min}\right)$, and the absorbance of the produced dopaquinone was measured using a microplate reader (SH-1000; Corona Electric Co. Ltd.) (measurement wavelength $405 \mathrm{~nm}$ ). Inhibition was measured as:

Inhibition $(\%)=[(A-B) / A] \times 100$

where $A$ is the absorbance without test sample (control); $B$ is the absorbance with test sample.

\section{Effects on melanoma tyrosinase activity}

Inhibitory effects on melanoma tyrosinase activity were examined using methods described elsewhere, with slight modifications [31-33]. B16 melanoma 4A5 cells were cultured for $72 \mathrm{~h}$, and the cells were then detached by trypsin treatment, collected, and washed with PBS. Then, $1 \mathrm{~mL}$ of $0.1 \%$ Triton $\mathrm{X}-100$ in phosphate buffer solution (pH 6.5) was added. The cells were disrupted using an ultrasonic cell disruptor under cooling with ice and then centrifuged at 11,000 $g$ for $10 \mathrm{~min}$. The supernatant was used as the crude enzyme solution, and the amount of enzyme was quantified using an enzymatic reaction, as follows. Phosphate buffer solution ( $\mathrm{pH}$ 6.5) containing $2.5 \mathrm{mM}$ L-DOPA $(80 \mu \mathrm{L} /$ well $)$ was dispensed into a $96-$ well microplate, and $10 \mu \mathrm{L}$ of test substance (DMSO solution) was added. Next, crude tyrosinase solution was diluted with phosphate buffer solution (pH 6.5) to $10 \mu \mathrm{g} / \mathrm{mL}$ protein. The diluted enzyme solution was add to each well $(10 \mu \mathrm{L} /$ well $)$, and the enzymatic reaction $\left(37^{\circ} \mathrm{C}\right)$ was carried out for $24 \mathrm{~h}$. A microplate reader (SH-1000; Corona Electric Co., Ltd.) was used to measure the absorbance of melanin (measurement wavelength $405 \mathrm{~nm})$. Inhibition was measured as: 
Inhibition $(\%)=[(A-B) / A] \times 100$

where $A$ is the absorbance without test sample (control); $B$ is the absorbance with test sample.

\section{Effects on autoxidation}

The autoxidation of dopachrome was performed according to previously reported methods, with slight modifications $[36,37]$. A phosphate buffer solution $(125 \mu \mathrm{L})$ containing mushroom-derived tyrosinase (150 units/mL, pH 6.5) was pre-incubated at $25{ }^{\circ} \mathrm{C}$ for $10 \mathrm{~min}$. Then, $125 \mu \mathrm{L}$ of $0.03 \%$ L-DOPA phosphate buffer solution was added, and the incubation was carried on for a further $10 \mathrm{~min}$. Next, $125 \mu \mathrm{L}$ of test sample (DMSO solution) was added, and the reaction was allowed to proceed for $60 \mathrm{~min}\left(25^{\circ} \mathrm{C}\right)$. To terminate the reaction, $50 \mu \mathrm{L}$ of $1.0 \mathrm{M} \mathrm{HCl}$ solution was added, and the solution centrifuged conducted at 10,000 $\mathrm{g}$ for $15 \mathrm{~min}$. After the residue was washed with ethanol, it was dissolved in $1 \mathrm{~mL}$ of Soluene-350 $\left(60^{\circ} \mathrm{C}\right)$, and the absorbance of the melanin produced was measured using a microplate reader (SH-1000; Corona Electric Co. Ltd.) (wavelength 405 nm). Inhibition was measured as:

Inhibition $(\%)=[(A-B) / A] \times 100$

where $A$ is the absorbance without test sample (control); $B$ is the absorbance with test sample.

\section{Effects on MITF, tyrosinase, TRP-1, and TRP-2 protein levels}

B16 melanoma 4A5 cells $\left(1.0 \times 10^{5}\right.$ cells $/ 2 \mathrm{~mL} /$ well $)$ were seeded in a 6-well multiwell plate and pre-incubated for $24 \mathrm{~h}$, following which the test sample and theophylline (final concentration $1 \mathrm{mM}$ ) were added and the cell solution incubated for a further $72 \mathrm{~h}$. Then, $140 \mu \mathrm{L}$ of lysis buffer was added after washing with PBS. Cells detached with a cell scraper were disrupted with an ultrasonic cell disruptor under cooling with ice to extract the protein. The supernatant was centrifuged at $11,000 \mathrm{~g}$ for $10 \mathrm{~min}$. The amount of protein was determined by the Lowry method and denatured at $100{ }^{\circ} \mathrm{C}$ for $5 \mathrm{~min}$.

An aliquot of extracted protein $(20 \mu \mathrm{g} / \mathrm{lane})$ was electrophoresed on $10 \%$ sodium dodecyl sulfate-polyacrylamide gels for $1 \mathrm{~h}$, washed with Tris-buffered saline (T-TBS), and transferred to a membrane (PVDF membrane) using a transfer device. After washing with T-TBS, blocking was carried out with Blocking One (Nacalai Tesque, Inc., Kyoto, Japan) for $1 \mathrm{~h}$, and incubation was commenced with primary antibody against each protein in 5\% Blocking One/T-TBS solution $(0.2 \mu \mathrm{g} / \mathrm{mL})$ for $1 \mathrm{~h}$. After washing with T-TBS, the membrane was incubated with horseradish peroxidase-conjugated secondary antibody in 5\% Blocking One/T-TBS solution $(0.3 \mu \mathrm{g} / \mathrm{mL})$ for $1 \mathrm{~h}$. Immunoreactive proteins were detected using a chemiluminescence kit (Chemi-Lumi One; Nacalai Tesque) according to the manufacturer's instructions. Each target band was measured by a lumino image analyzer (LAS4000 mini; Fujifilm, Tokyo Japan); Multi Gauge V3.0 software was used to analyze the data (Fujifilm).

The primary antibody was diluted 1000-fold. Anti-tyrosinase (goat), anti-TRP-1 (rabbit), and anti-TRP-2 (rabbit) were purchased from Santa Cruz Biotechnology (Dallas, TX, USA). Anti-MITF (rabbit) and anti- $\beta$-actin (rabbit) were from Cell Signaling Technology (Tokyo, Japan). The secondary antibody was diluted 4000-fold. Anti-rabbit antibody was from Cell Signaling Technology and rabbit anti-goat antibody was from Thermo Fisher Scientific (Waltham, MA, USA).

\section{Statistical analysis}

Values were expressed as the mean \pm standard error of the mean. A one-way analysis of variance followed by Dunnett's test was used to determine the statistical significance of the differences between the control group and test sample-treated groups. $P$ values of $<0.05$ were regarded as significant.

Acknowledgements This work was partly supported by JSPS KAKENHI Grant Number 16K08312 (H.M.).

\section{Compliance with ethical standards}

Conflict of interest M. Yoshikawa and $\mathrm{H}$. Matsuda have been received research Grants from N.T.H Co., Ltd. All other authors declare that they have no conflicts of interest.

Open Access This article is licensed under a Creative Commons Attribution 4.0 International License, which permits use, sharing, adaptation, distribution and reproduction in any medium or format, as long as you give appropriate credit to the original author(s) and the source, provide a link to the Creative Commons licence, and indicate if changes were made. The images or other third party material in this article are included in the article's Creative Commons licence, unless indicated otherwise in a credit line to the material. If material is not included in the article's Creative Commons licence and your intended use is not permitted by statutory regulation or exceeds the permitted use, you will need to obtain permission directly from the copyright holder. To view a copy of this licence, visit http://creativecommons.org/licenses/by/4.0/.

\section{References}

1. Goding CR (2007) Melanocytes: the new black. Int J Biochem Cell Biol 39:275-279

2. Sulaimon SS, Kitchell BE (2003) The biology of melanocytes. Vet Dermat 14:57-65

3. Sato N (1987) Endocrine environment in adult females with chloasma. Nihon Hifuka Gakkai Zasshi 97:937-943

4. Wu S, Shi H, Wu H, Yan S, Guo J, Sun Y, Pan L (2012) Treatment of melasma with oral administration of tranexamic acid. Aesthetic Plast Surg 36:964-970 
5. Sealy RC, Felix CC, Hyde JS, Swartz HM (1980) Structure and reactivity of melanins: influence of free radicals and metal ions. Free Radic Biol 4:209-259

6. Debing I, Ijzerman AP, Vauquelin G (1988) Melanosome binding and oxidation-reduction properties of synthetic L-DOPA-melanin as in vitro tests for drug toxicity. Mol Pharmacol 33:470-476

7. Testorf M, Kronstrand R, Svensson SPS, Lundström I, Ahlner J (2001) Characterization of $\left[{ }^{3} \mathrm{H}\right]$ flunitrazepam binding to melanin. Anal Biochem 298:259-264

8. Matsuda H, Nakashima S, Oda Y, Nakamura S, Yoshikawa M (2009) Melanogenesis inhibitors from the rhizomes of Alpinia officinarum in B16 melanoma cells. Bioorg Med Chem 17:6048-6053

9. Nakashima S, Matsuda H, Oda Y, Nakamura S, Xu F, Yoshikawa M (2010) Melanogenesis inhibitors from the desert plant Anastatica hierochuntica in B16 melanoma cells. Bioorg Med Chem 18:2337-2345

10. Nakamura S, Chen G, Nakashima S, Matsuda H, Pei Y, Yoshikawa M (2010) Brazilian natural medicines. IV. New noroleanane-type triterpene and ecdysterone-type sterol glycosides and melanogenesis inhibitors from the roots of Pfaffia glomerata. Chem Pharm Bull 58:690-695

11. Nakamura S, Fujimoto K, Nakashima S, Matsumoto T, Miura T, Uno K, Matsuda H, Yoshikawa M (2012) Medicinal flowers. XXXVI. Acylated oleanane-type triterpene saponins with inhibitory effects on melanogenesis from the flower buds of Chinese Camellia japonica. Chem Pharm Bull 60:752-758

12. Nakamura S, Moriura T, Park S, Fujimoto K, Matsumoto T, Ohta T, Matsuda H, Yoshikawa M (2012) Melanogenesis inhibitory and fibroblast proliferation accelerating effects of noroleanane- and oleanane-type triterpene oligoglycosides from the flower buds of Camellia japonica. J Nat Prod 75:1425-1430

13. Fujimoto K, Nakamura S, Nakashima S, Matsumoto T, Uno K, Ohta T, Miura T, Matsuda H, Yoshikawa M (2012) Medicinal flowers. XXXV. Nor-oleanane-type and acylated oleanane-type triterpene saponins from the flower buds of Chinese Camellia japonica and their inhibitory effects on melanogenesis. Chem Pharm Bull 60:1188-1194

14. Nakamura S, Nakashima S, Tanabe G, Oda Y, Yokota N, Fujimoto K, Matsumoto T, Sakuma R, Ohta T, Ogawa K, Nishida S, Miki H, Matsuda H, Muraoka O, Yoshikawa M (2013) Alkaloid constituents from flower buds and leaves of sacred lotus (Nelumbo nucifera, Nymphaeaceae) with melanogenesis inhibitory activity in B16 melanoma cells. Bioorg Med Chem 21:779-787

15. Nakamura S, Nakashima S, Oda Y, Yokota N, Fujimoto K, Matsumoto T, Ohta T, Ogawa K, Maeda S, Nishida S, Matsuda H, Yoshikawa M (2013) Alkaloids from Sri Lankan curry-leaf (Murraya koenigii) display melanogenesis inhibitory activity: structures of karapinchamines A and B. Bioorg Med Chem 21:1043-1049

16. Nakamura S, Fujimoto K, Matsumoto T, Nakashima S, Ohta T, Ogawa K, Matsuda H, Yoshikawa M (2013) Acylated sucroses and acylated quinic acids analogs from the flower buds of Prunus mume and their inhibitory effect on melanogenesis. Phytochemistry 92:128-136

17. Matsumoto T, Nakamura S, Nakashima S, Yoshikawa M, Fujimoto K, Ohta T, Morita A, Yasui R, Kashiwazaki E, Matsuda H (2013) Diarylheptanoids with inhibitory effects on melanogenesis from the rhizomes of Curcuma comosa in B16 melanoma cells. Bioorg Med Chem Lett 23:5178-5181

18. Matsumoto T, Nakamura S, Nakashima S, Fujimoto K, Yoshikawa M, Ohta T, Ogawa K, Matsuda H (2014) Lignan dicarboxylates and terpenoids from the flower buds of Cananga odorata and their inhibitory effects on melanogenesis. J Nat Prod 77:990-999

19. Morikawa T, Nakanishi Y, Ninomiya K, Matsuda H, Nakashima S, Miki H, Miyashita Y, Yoshikawa M, Hayakawa T, Muraoka O (2014) Dimeric pyrrolidinoindoline-type alkaloids with melanogenesis inhibitory activity in flower buds of Chimonanthus praecox. J Nat Med 68:539-549

20. Nakashima S, Oda Y, Nakamura S, Liu J, Onishi K, Kawabata M, Miki H, Himuro Y, Yoshikawa M, Matsuda H (2015) Inhibitors of melanogenesis in B16 melanoma 4A5 cells from flower buds of Lawsonia inermis (Henna). Bioorg Med Chem Lett 25:2702-2706

21. Nakamura $S, X u$ F, Ninomiya $K$, Nakashima S, Oda Y, Morikawa T, Muraoka O, Yoshikawa M, Matsuda H (2014) Chemical structures and hepatoprotective effects of constituents from Cassia auriculata leaves. Chem Pharm Bull 62:1026-1031

22. Nakamura S, Zhang Y, Nakashima S, Oda Y, Wang T, Yoshikawa M, Matsuda H (2016) Structures of aromatic glycosides from the seeds of Cassia auriculata. Chem Pharm Bull 64:970-974

23. Zhu JJ, Zhang CF, Zhang M, Bligh SW, Yang L, Wang ZM, Wang ZT (2010) Separation and identification of three epimeric pairs of new C-glucosyl anthrones from Rumex dentatus by on-line high performance liquid chromatography-circular dichroism analysis. J Chromatogra A 1217:5384-5388

24. Elsworth C, Gill M, Giménez A, Milanovic NM, Raudies E (1999) Pigments of fungi. Part 50. Structure, biosynthesis and stereochemistry of new dimeric dihydroanthracenones of the phlegmacin type from Cortinarius sinapicolor Cleland. J Chem Soc Perkin Trans 1:119-126

25. Prelog V, Helmchen G (1982) Basic principles of the CIP-system and and proposals for a revision. Angew Chem Int Ed Engl 21:567-583

26. Friedmann PS, Gilchrest BA (1987) Ultraviolet radiation directly induces pigment production by cultured human melanocytes. $\mathrm{J}$ Cell Physiol 133:88-94

27. Hunt G, Todd C, Cresswell JE, Thody AJ (1994) $\alpha$-Melanocyte stimulating hormone and its analogue Nle4DPhe $7 \alpha-\mathrm{MSH}$ affect morphology, tyrosinase activity and melanogenesis in cultured human melanocytes. J Cell Sci 107:205-211

28. Buscá R, Ballotti R (2000) Cyclic AMP a key messenger in the regulation of skin pigmentation. Pigment Cell Res 13:60-69

29. Steinberg ML, Whittaker JR (1976) Stimulation of melatonic expression in a melanoma cell line by theophylline. J Cell Physiol $87: 265-275$

30. Lerch K (1978) Amino acid sequence of tyrosinase from Neurospora crassa. Proc Natl Acad Sci USA75:3635-3639

31. Kwon BS, Haq AK, Wakulchik M, Kestler D, Barton DE, Francke U, Lamoreux ML, Whitney JB 3rd, Halaban R (1989) Isolation, chromosomal mapping, and expression of the mouse tyrosinase gene. J Invest Dermatol 93:589-594

32. Klabunde T, Eicken C, Sacchettini JC, Krebs B (1998) Crystal structure of a plant catechol oxidase containing a dicopper center. Nat Struct Biol 5:1084-1090

33. Takara K, Iwasaki H, Ujihara K, Wada K (2008) Human tyrosinase inhibitor in rum distillate wastewater. J Oleo Sci 57:191-196

34. Puiu M, Babaligea I, Olmazu C, Răucan A, Oancea D (2010) Peroxidase-mediated oxidation of L-dopa: a kinetic approach. Biochem Eng J 52:248-254

35. Austria R, Semenzato A, Bettero A (1997) Stability of vitamin C derivatives in solution and topical formulations. J Pharm Biomed Anal 15:795-801

36. Mason HS, Peterson EW (1965) Melanoproteins. I. Reactions between enzyme-generated quinones and amino acids. Biochim Biophys Acta 111:134-146

37. Matsuda H, Higashino M, Nakai Y, Iinuma M, Kubo M, Lang FA (1996) Studies of cuticle drugs from natural sources. IV. Inhibitory effects of some Arctostaphylos plants on melanin biosynthesis. Biol Pharm Bull 19:153-156

Publisher's Note Springer Nature remains neutral with regard to jurisdictional claims in published maps and institutional affiliations. 